\title{
Ellipsis
}

2014

\section{Blue Falsetto after Frank Stanford's "Blue Yodel of Her Feet"}

M. E. Riley

Follow this and additional works at: https://scholarworks.uno.edu/ellipsis

Part of the Creative Writing Commons

\section{Recommended Citation}

Riley, M. E. (2014) "Blue Falsetto after Frank Stanford's "Blue Yodel of Her Feet"," Ellipsis: Vol. 41 , Article 4. DOI: https://doi.org/10.46428/ejail.41.04

Available at: https://scholarworks.uno.edu/ellipsis/vol41/iss1/4

This Poetry is brought to you for free and open access by the Department of English and Foreign Languages at ScholarWorks@UNO. It has been accepted for inclusion in Ellipsis by an authorized editor of ScholarWorks@UNO. For more information, please contact scholarworks@uno.edu. 


\section{Blue Falsetto \\ after Frank Stanford's "Blue Yodel of Her Feet" \\ M. E. Riley \\ Vassar Miller Poetry Award Winner}

You won't look me in the face I'm a hound that's killed

things we once loved so you look

my feet paled from winter paws

roughened by gravel stiff branches they

hardly hold the weight of my body cold

statue you admire

Your waist is a place your chest gives ground

sandbar by river hums a summer song

I wish I could keep you barefoot and dance

lightly around young plants bearing in dry soil

Too much to raise your eyes across the rest of me

you look at my feet yours walked

over spring ground where you found me

cover same terrain when you leave 